\title{
Isolation and identification of plasmids of bacteria from petroleum products contaminated soil
}

\begin{abstract}
Isolation and Identification of Plasmids of Bacteria from Petroleum Products Contaminated Soil was carried out. Hydrocarbon utilizing bacteria were isolated from petroleumproducts contaminated soil from the tank farm of NNPC/PPMC Depot in Benin City, Nigeria. Plasmid analysis of bacteria was carried out showing the presence of plasmids in seven isolates: Bacillus subtilis, Bacillus species, Arthorbacter species, Pseudomonas aeroginosa, Klebsiella aerogenes, Alcaligenes species, and Pseudomonas species. All the plasmids corresponds to $23 \mathrm{kbp}$ of the maker. The result of the DNA extracted and amplified in a PCR using the ndoB primers indicated no visible bands, showing that ndoB primers is not specific for bacteria isolates in the samples, hence there was no amplification. The none specification of ndoB gene of isolates does not imply the absence of plasmids DNA that confers utilizing ability to it, but that the utilizing gene could possibly be borne on the chromosomal DNA which enabled its persistence in the contaminated soil or other genes which were tested such as catechol 2,3 dioxygenase (C23DO) and monoxygenase could be present.
\end{abstract}

Volume 5 Issue 6 - 2017

\author{
Akeredolu DO,' Akinnibosun FI,' \\ Udochukwu UI, ${ }^{2}$ \\ 'Department of Microbiology, University of Benin, Nigeria \\ ${ }^{2}$ Department of Biosciences, Salem University, Nigeria
}

Correspondence: Akeredolu DO, Department of Microbiology, University of Benin, Benin City, Nigeria,Tel 09099746844, Email dennisakeredolu@gmail.com

Received: July 29, 2017 | Published: November 29, 2017

Keywords: bacteria, plasmid dna, petroleum products, contaminated soil

\section{Introduction}

Many important processes influence the destination of hydrocarbons in the environment. Among these are sorption, volatilization, abiotic transformation (chemical or photochemical), and biotransformation. ${ }^{1}$ Biodegradation of oil contaminated soils, which exploits the ability of microorganisms to degrade and/or detoxify organic contamination, has been established as one of the efficient, economic, versatile and environmentally sound treatment. ${ }^{2}$ The study of identification of bacteria is important in microbial ecology, especially with molecular techniques. ${ }^{3}$ In particular, analysis of the microbial communities that take part in in-situ hydrocarbon biodegradation activities has been a challenge to microbiologist. Interest in this area has been catalyzed by the rapid advancement of molecular ecological methodologies. ${ }^{4}$ Hydrocarbon utilizing microorganisms are ubiquitously distributed in the environment following oil spills. These microorganisms are naturally degraded numerous contaminating petroleum hydrocarbons and cleansing of oil pollutants. The ability of microorganisms to degrade an organic compound is the result ultimately of the genetic makeup of the organisms. The chemical reactions involved in metabolism are mediated by enzymes. The range of enzymes which a bacterium has is a reflection of the specific genetic information in the cell. Genetic information in bacteria, as in all organisms, is stored in the form of DNA. The information is physically present in bacterial cells in two forms the chromosome and the plasmids. The bacterial chromosome is a single circular, highly folded double-strand of DNA. In addition to chromosomal DNA, a larger number of bacteria also have extra-chromosomal DNA in the form of plasmids. ${ }^{5}$ Many plasmids contain genes which code for the enzymes necessary for the derivative pathways important to bioremediation. Enzymes involved in the degradation of toluene, naphthalene, salicylate, octane have been shown to be plasmid encoded. ${ }^{6}$ This research focused on the Isolation and Identification of Plasmids of Bacteria from Petroleum Products Contaminated Soil.

\section{Materials and methods}

\section{Plasmid extraction}

Plasmid extraction was done using the alkaline lyses method. ${ }^{7}$ This was carried out by labelling Eppendorf tubes according to number of isolates and filled with $1 \mathrm{ml}$ of sterile water. Bacterial growth was mix by vortexing. One and half (1.5) $\mathrm{ml}$ of the broth was taken into the labelled tubes and centrifuged at $13,000 \mathrm{rpm}$ for $2 \mathrm{mins}$. The supernatant was discarded by decanting gently leaving a little of the broth. This was then vortexed at high speed until pellet is completely suspended in broth. Three hundred $(300 \mu 1)$ of TENS solution and mix by inverting tubes until the solution becomes slimy. A hundred and fifty $(150 \mu \mathrm{l})$ of sodium acetate solution was added and vortex for about $10 \mathrm{mins}$ and thereafter centrifuge at $13,000 \mathrm{rpm}$ for 5 minutes. The supernatant was transferred into another $1.5 \mathrm{ml}$ Eppendorf tube. Nine hundred $(900 \mu \mathrm{l})$ of ice cold absolute ethanol was added, vortex and centrifuge at $13,000 \mathrm{rpm}$ for 10 minutes. White pellet is observed after supernatant is discarded. A thousand $(1000 \mu 1)$ of ice cold $70 \%$ ethanol was added and centrifuge at $13,000 \mathrm{rpm}$ for 5 minutes (no vortexing at this stage). Supernatant was discarded and pellets allowed to dry then add $40 \mu 1$ of TE buffer. The plasmids were characterized using agarose gel electrophoresis. ${ }^{8}$ The molecular weights of plasmids were visualized using UV transilluminator.

\section{DNA extraction}

DNA was extracted using the boiling method which is an alternative method for isolation of DNA from both Gram negative and Gram positive organisms. In this procedure, bacterial cells were harvested into $1 \mathrm{ml}$ of sterile water, vortex and centrifuge at 10,000 rpm for 5 minutes. Again, it was washed with $1 \mathrm{ml}$ of sterile water. $200 \mu 1$ of sterile water was added, vortex and boil at $95-100^{\circ} \mathrm{C}$ for 10 minutes. It was vortex again centrifuge at $10,000 \mathrm{rpm}$ for 5 minutes. The supernatant was transferred into another tube and stored at $-20^{\circ} \mathrm{C}$ and use for PCR. 


\section{PCR analysis}

The primer used for the DNA amplification was ndob and $5 \mathrm{X}$ FIREPol master mix (Solis BioDyne). In this reaction mix, samples were labelled accordingly on top of the Eppendorf tube. Fourteen $(14 \mu \mathrm{l})$ of sterile de-ionized water was taken and $4 \mu \mathrm{l}$ of PCR buffer (5X FIREPol Master mix), $0.5 \mu 1$ of the primer (ndob) and $1.5 \mu 1$ of extracted DNA were added and vortexed at low speed. The centrifuge was pulsed and placed in the thermal cycler. The constituted reaction was denatured at $95^{\circ} \mathrm{C}$ for 3 minutes. Cycling began with denaturing at $95^{\circ} \mathrm{C}$ for 30 seconds, annealing at $50^{\circ} \mathrm{C}$ for 30 seconds and $72^{\circ} \mathrm{C}$ for $1 \mathrm{~min}$; and a final 10 -min extension step at $72^{\circ} \mathrm{C}$. All reaction mixtures were held at $4^{\circ} \mathrm{C}$ until analyzed. Following optimization, all reactions were performed in repeated cycles for a total of 30 cycles in an Eppendorf thermocycler. All experiments included controls without any added DNA. This involved four basic steps cell harvest, lyses, deproteination and decontamination.

\section{Results and discussion}

While a total of nine hydrocarbon-utilizing bacteria were obtained as shown in Table 1. Again, the hydrocarbon-utilizing isolates were highest in PMS while that of pure DPK was lowest. Figure 1 shows bands of plasmid DNA for Bacillus subtilis, Micrococcus varians, Corynebacteria specie, Bacillus specie, and Arthrobacter specie. The bands indicate that Bacillus subtilis, Micrococcus varians and Bacillus specie. Plasmid DNA with molecular weights corresponding to $23130 \mathrm{bp}$. While Figure 2 shows DNA plasmids in Pseudomonas aeroginosa, Klebsiella aerogenes, Alcaligenes specie and Pseudomonas specie. Corresponding to $23 \mathrm{kpb}$ markers. Figure 3 shows bands of amplified DNA of isolates using the naphthalene dioxygenase (ndoB) primers. There was no visible band observed for the nine isolates, showing that the organism does not have an ndoB gene that confers utilizing ability. These findings are not unexpected, because there are numerous reports to show genetic diversity among degradative genes.

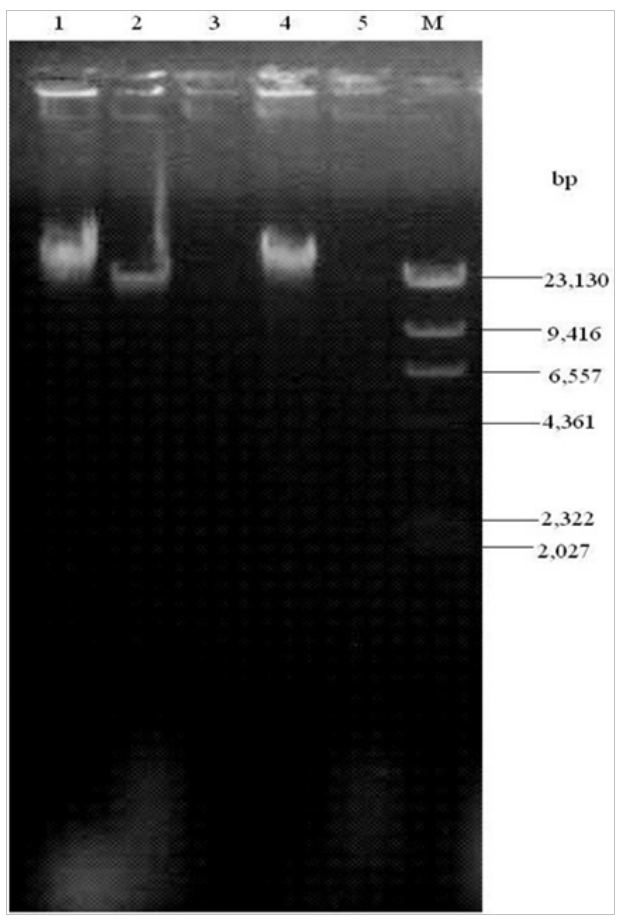

Figure I Plasmid result of Gram positive bacteria: lane I: Bacillus subtilis, lane 2: Micrococcus varians, lane 3: Corynebacteria sp: lane 4. Bacillus specie and lane 5: Arthrobacter specie.

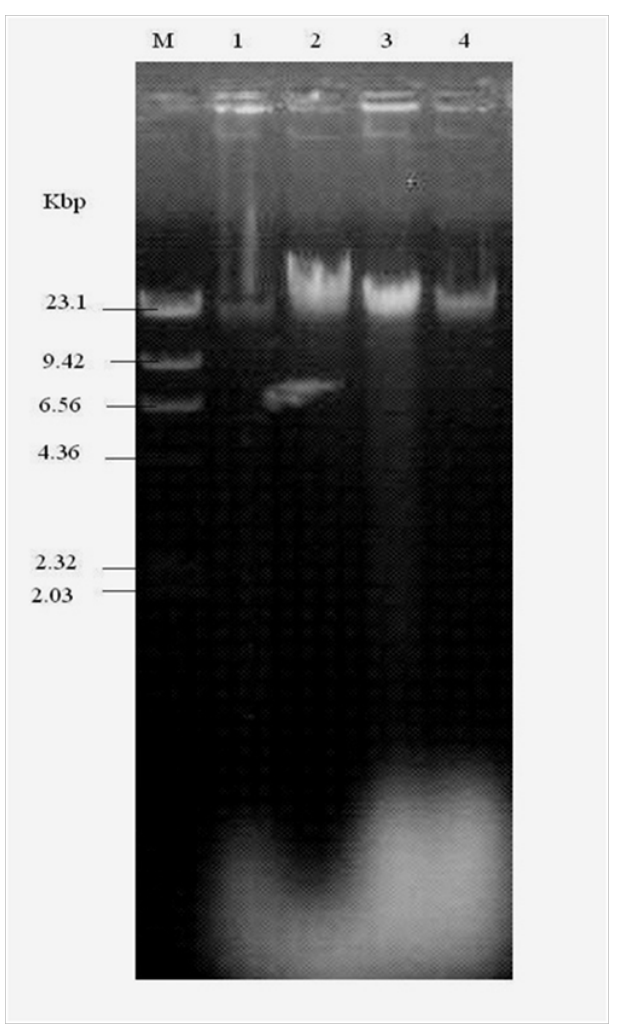

Figure 2 Plasmid results for Gram negative bacteria: lane I: Pseudomonas aeruginosa, lane 2: Klebsiella aerogenes, lane 3: Alcaligenes specie, lane 4: Pseudomonas specie.

Table I Hydrocarbon utilizing bacteria (cfu/ml)

\begin{tabular}{ll}
\hline Samples & Viable cell count $(\mathrm{cfu} / \mathrm{ml})$ \\
\hline Pure DPK & $6.7 \pm 1.45 \times 103$ \\
Mixed DPK & $1.16 \pm 0.12 \times 104$ \\
AGO & $1.93 \pm 0.15 \times 104$ \\
PMS & $4.27 \pm 0.27 \times 104$ \\
\hline
\end{tabular}

Key: DPK, dual purpose kerosene;AGO, automobile oil and gas; PMS, premium motor spirit.

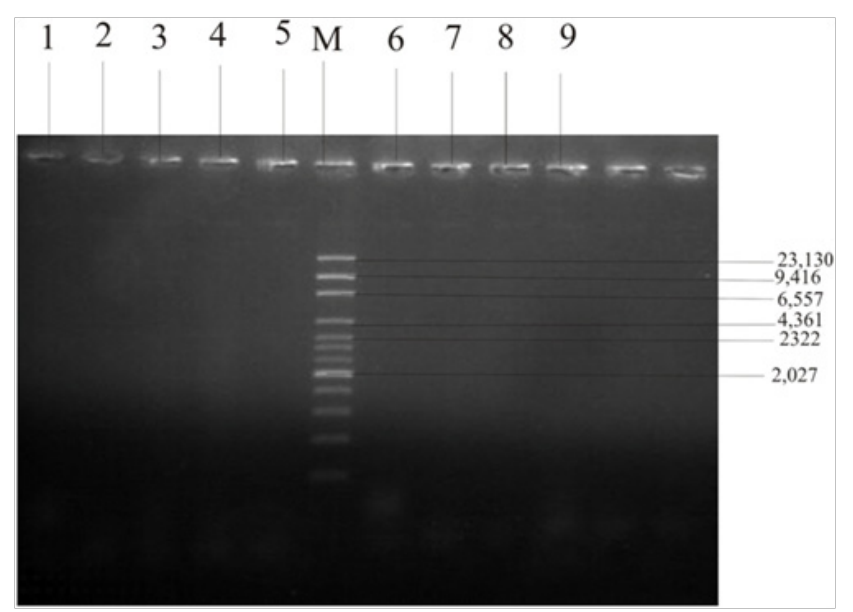

Figure 3 Result of PCR with ndoB-specific primers. Lane I: Bacillus subtilis; lane 2: Micrococcus varians, lane 3: Pseudomonas aeruginosa, lane 4: Klebsiella aerogenes, lane 5: Alcaligenes specie, lane 6: Corynebacterium specie, lane 7: Bacillus specie, lane 8: Arthrobacter specie and Lane 9: Pseudomonas specie. 
The plasmid profile of the isolates which we classified into Gram positive and Gram negative shows that there are plasmid in lane 1, 2 and 4 (Bacillus subtilis, Bacillus specie. and Arthrobacter specie.) which corresponds to $23 \mathrm{Kbp}$ of the marker. While the Gram negative indicate that lane 1, 2 and 3and 4 (Pseudomonas species, Klebsiella aerogenes, Alcaligenes specie. and Pseudomonas specie) also shows there were plasmids that correspond to $23 \mathrm{kbp}$ of the standard. PCR of the genomic DNA of all the nine isolates were negative to ndoB primers as can be seen on Figure 3. These findings are not unexpected, because there are numerous reports to show genetic diversity among degradative genes. Among 20 PAH-degrading isolates, strong hybridization signals with ndoB were only observed in seven of eight naphthalene-degrading Pseudomonas strains. ${ }^{8}$ In 1989, Furukawa found that only five Pseudomonas species of 15 biphenyldegrading Pseudomonas, Achromobacter, Alcaligenes, Moraxella and Arthrobacter strains showed significant hybridization tobphABC of Pseudomonas pseudoalcaligenes KF 707. Also ${ }^{9,10}$ observed no visible band for cuts made with EcoRV restriction enzyme for Klebsiella. From the forgoing, we cannot conclude that these bacteria do not have utilizing genes or that the degradation is plasmid mediated. But that other primers which were not available in the laboratory as of this work could detect their degradative genes.

\section{Conclusion}

Plasmid analysis of bacteria isolated show molecular sizes of the plasmid DNA molecules. No visible band was observed for the isolated bacteria indicating the organisms lack plasmid DNA that could be borne on the chromosomal DNA which enabled its persistence in the polluted soil. The presence of Pseudomonas species in all the hydrocarbon contaminated soil revealed its crude oil utilizing potential and hence should be considered the first choice in bioremediation of hydrocarbon polluted sites.

\section{Acknowledgements}

None.

\section{Conflict of interest}

The author declares no conflict of interest.

\section{References}

1. Johnson JR, Sannes MR, Croy C, et al. Antimicrobial drug-resistant Escherichia coli from human and poultry products, Minnesota and Wiseonsin. Emerg Infect Dis. 2007;13(6):838-846.

2. Lues JF, Theron MM, Venter P, et al. Microbial composition in bioaerosols of a high-throughput chicken slaughtering facility. Poutry science. 2007;86(1):146-152.

3. Watanabe K, Hamamura N. Molecular and physiological approaches to understanding the ecology of pollutant degradation. Curr Opin Biotechnol. 2003;14(3):289-295.

4. MacNaughton SJ, Stephen JR, Venosa AD, et al. Microbial Population Changes during Bioremediation of an Experimental Oil Spill. Applied and Environmental Microbiology. 1999;65(8):3566-3574.

5. Atuanya E, Tudararo-Aherobo L. Ecotoxicological effects of discharge of Nigerian petroleum refinery oily sludge on the biological sentinels. African Journal of Environmental Science and Technology. 2014;9(2):95-103.

6. Sheikh AR, Afsheen A, Sadia K, et al. Plasmid borne antibiotic resistance factors among indigenous Klebsiella. Pak J. 2003;35(2):243-248.

7. Ilori MON, Amund DL. Degradation of anthracene by bacteria isolated from oil polluted tropical soils. Z Naturforsch. 2000;55(11-12):890-897.

8. Itah AY, Essien JP. Growth profile and hydrocarbonoclastic potential of micro-organisms isolated from tarballs in the bight of bonny. Nigeria. World J Microbial Biotechnol. 2005;21(6-7):1317-1322.

9. John RC, Akpan MM, Essien JP, et al. Impact of crude oil pollution on the densities of nitrifying and denitrifying bacteria in the rhizosphere of tropical legumes grown on wetland soil. Niger J Microbiol. 2010;24(1):2088-2094.

10. Ogbulie TE, Ogoamaka AI, Udensi JU. Plasmid profilling and similarities in identities of probable microbes isolated from crude oil contaminated agricultural soil. Analele Universităţiidin Oradea, Fascicula Biologie Tom. 2013;20(1):7-11. 